Crop Breeding and Applied Biotechnology 10: 298-304, 2010

Brazilian Society of Plant Breeding. Printed in Brazil

\title{
Breeding potential and genetic diversity of "Híbrido do Timor" coffee evaluated by molecular markers
}

Tesfahun Alemu Setotaw $^{1}$, Eveline Teixeira Caixeta ${ }^{2} *$, Guilherme Ferreira Pena ${ }^{1}$, Eunize Maciel Zambolim ${ }^{1}$, Antonio Alves Pereira ${ }^{3}$ and Ney Sussumu Sakiyama ${ }^{1}$

Received 10 December 2009

Accepted 20 June 2010

\begin{abstract}
AFLP, RAPD and SSR molecular markers were used to study the genetic diversity and genetic structure of the Hibrido de Timor germplasm. The principal coordinate analysis, UPGMA cluster analysis based on genetic dissimilarity of Jaccard, Bayesian model-based cluster analysis, percentage of polymorphic loci, Shannon's information index and Nei gene diversity were employed to assess the genetic diversity. The analyses demonstrated a high genetic diversity among Hibrido de Timor accessions. UPGMA and Bayesian cluster analyses grouped the accessions into three clusters. The genetic structure of Hibrido de Timor is reported. The management of Hibrido de Timor germplasm variability and its potential use in breeding programs are discussed.
\end{abstract}

Key words: Coffee breeding, DNA markers, rust resistance, Bayesian analysis, principal coordinate analysis.

\section{INTRODUCTION}

"Híbrido de Timor" coffee, a natural interspecific hybrid between $C$. arabica $\mathrm{L}$ and $C$. canephora Pierre $e x$ Froehner was first found in a plantation of cultivar Typica in Timor Island in 1917 (Bettencourt 1973). The derivatives of this coffee tree have been used as a source of resistance gene for economically important diseases and pests of coffee such as coffee leaf rust (Hemileia vastatrix), coffee berry disease (CBD) caused by Colletotrichum Kahawae, root knot nematode (Meloidogyne exigua) and bacteriosis caused by Pseudomonas syringae pv garçae (Bettencourt 1973, Chaves 1976, Goncalves and Pereira 1998, Carvalho et al. 1989, Pereira et al. 2005). Cultivars derived from "Híbrido de Timor" were released for production in Kenya, Brazil, Colombia and Costa Rica (Charrier and Eskes 1997,
Lashermes et al. 2000, Sera 2001, Pereira et al. 2005, Sera et al. 2008).

The first introduction of "Híbrido de Timor" accessions to Brazil date back from 1976 via vegetative propagation and seeds from CIFC (Centro da Investigação de Ferrugem do Café, Portugal), IIAA (Instituto Investigação Agronomia de Angola) and ERU (Estação Regional de Uige) (Pereira et al. 2002). These materials were used extensively in the breeding program of coffee for resistance to diseases and pests in Brazil.

Since "Híbrido de Timor" is an important gene source for resistance to diseases and used to a large extent in the breeding program of coffee in the world, understanding the existing genetic variability will be very important and it will help in designing the breeding strategies to develop cultivars which combine good cup quality with resistance

\footnotetext{
${ }^{1}$ Universidade Federal de Viçosa (UFV), Laboratório de Biotecnologia do Cafeeiro (BIOCAFÉ), BIOAGRO, 36570-000, Viçosa, MG, Brazil.

${ }^{2}$ Embrapa Café, 70770-901, Brasília, DF, Brazil. Current address: UFV, BIOCAFÉ.*E-mail: eveline.caixeta@embrapa.br

${ }^{3}$ Empresa de Pesquisa Agropecuária de Minas Gerais, Centro Técnico da Zona da Mata Mineira, Vila Gianeti, casas 46 e 47, C.P. 216, 36570-000, Viçosa, MG, Brazil.
} 
to disease. In addition, it is important to plan appropriate conservation strategies to maintain and conserve the accessions of "Híbrido de Timor". The study of genetic diversity among accessions also helps to identify the duplicated accessions in the germplasm bank and planning appropriate selections to form the core collection. The existence of considerable genetic diversity within the Híbrido de Timor germplasm was reported by Lashermes et al. (2000) but he included only two accessions. So it is important to study the genetic variability including more accessions of "Híbrido de Timor". To study the genetic variability, morphological, isoenzyme and molecular techniques can be used. Among them, the DNA molecular technique is the best and able to detect differences at the genome level. Among the molecular technique Simple Sequence Repeats (SSR), Random Amplified Polymorphic DNA(RAPD) and Amplified Fragment Length Polymorphism (AFLP) are more frequently used for genetic diversity study and proved to be efficient in establishing the core collection. Teixeira-Cabral et al. (2002) and Teixeira-Cabral et al. (2004) used RAPD molecular markers to study the genetic diversity and characterize the coffee differentials of Hemileia vastatrix races. Lashermes et al. (2000), OrozcoCastillo et al. (1994), Silvestrini et al. (2007) and Silvestrini et al. (2008) used AFLP, RAPD and SSR techniques to study the genetic diversity of coffee species. Maluf et al. (2005) used RAPD, AFLP and SSR molecular markers to study the genetic diversity of arabica coffee and detected significant polymorphism among lines. EST-SSR molecular markers were also used to study the genetic diversity of coffee trees including accessions of "Híbrido de Timor" (Missio et al. 2009).

This work was realized with the objective of investigating the existing genetic diversity among the accessions of "Híbrido de Timor" using RAPD, AFLP and SSR molecular markers.

\section{MATERIAL AND METHODS}

\section{Genetic materials and DNA extraction}

Forty eight accessions from the germplasm bank of UFV (Universidade Federal de Viçosa)/EPAMIG (Empresa de Pesquisa Agropecuária de Minas Gerais) were analyzed (Table 1).

The DNA of the genotypes was extracted according to the method described by Diniz et al. (2005) from young green leaves collected from each genotype. The DNA concentration was quantified using Spectrophotometer Smart Spec of BioRad. The extracted DNA was diluted

Table 1. Coffee accessions of Híbrido de Timor germplasm investigated for genetic diversity in this research

\begin{tabular}{|c|c|c|c|c|c|}
\hline Code & Genotype Name & Origin & Code & Genotype Name & Origin \\
\hline 1 & CIFC $832 / 1$ & Vegetative propagation $^{a}$ & 23 & UFV 427-09 & ERU202/13(CIFC1343/136) \\
\hline 2 & CIFC $832 / 2$ & Vegetative propagation & 24 & UFV 427-15 & ERU202/13(CIFC1343/136) \\
\hline 3 & CIFC 4106 & Vegetative propagation & 25 & UFV $427-22$ & ERU202/13(CIFC1343/136) \\
\hline 4 & CIFC $1343 / 269$ & Vegetative propagation & 26 & UFV $427-55$ & ERU202/13(CIFC1343/136) \\
\hline 5 & UFV 376-01 & IIAA808-5 (CIFC 2234) & 27 & UFV 427-56 & ERU202/13(CIFC1343/136) \\
\hline 6 & UFV 376-04 & IIAA808-5 (CIFC 2234) & 28 & UFV 427-65 & ERU202/13(CIFC1343/136) \\
\hline 7 & UFV 376-05 & IIAA808-5 (CIFC 2234) & 29 & UFV 427-90 & ERU202/13(CIFC1343/136) \\
\hline 8 & UFV 376-35 & IIAA808-5 (CIFC 2234) & 30 & UFV 438-52 & ERU209/13 (CIFC2570) \\
\hline 9 & UFV 376-37 & IIAA808-5 (CIFC 2234) & 31 & UFV 439-02 & ERU209/2 (CIFC2570) \\
\hline 10 & UFV $376-52$ & IIAA808-5 (CIFC 2234) & 32 & UFV $440-22$ & ERU209/6 (CIFC2570) \\
\hline 11 & UFV $376-57$ & IIAA808-5 (CIFC 2234) & 33 & UFV $442-108$ & ERU209/14 (CIFC2570) \\
\hline 12 & UFV $376-79$ & IIAA808-5 (CIFC 2234) & 34 & UFV 443-03 & ERU209/7 (CIFC2570) \\
\hline 13 & UFV 377-01 & IIAA811-7 (CIFC 2235) & 35 & UFV 446-08 & ERU209/8 (CIFC2570) \\
\hline 14 & UFV 377-02 & IIAA811-7 (CIFC 2235) & 36 & UFV 445-46 & ERU209/15 (CIFC2570) \\
\hline 15 & UFV $377-23$ & IIAA811-7 (CIFC 2235) & 37 & UFV 428-04 & ERU202/3 (CIFC1343/136) \\
\hline 16 & UFV $377-24$ & IIAA811-7 (CIFC 2235) & 38 & UFV 432-07 & ERU207/6 (CIFC2568) \\
\hline 17 & UFV $377-34$ & IIAA811-7 (CIFC 2235) & 39 & UFV 437-06 & ERU209/1 (CIFC2570) \\
\hline 18 & UFV 379-07 & IIAA845-5 (CIFC 2252) & 40 & UFV $441-03$ & ERU209/10 (CIFC2570) \\
\hline 19 & UFV 408-18 & CIFC $1590 / 9^{c}$ & 41 & UFV $447-48$ & ERU209/12 (CIFC2570) \\
\hline 20 & UFV 408-26 & CIFC $1590 / 9$ & 42 & UFV 448-69 & ERU209/16 (CIFC2570) \\
\hline 21 & UFV 408-28 & CIFC $1590 / 9$ & 43 & UFV 450-61 & ERU209/15 (CIFC2571) \\
\hline 22 & UFV 427-01 & ERU202/13(CIFC1343/136) & 44 & UFV 451-41 & $?$ \\
\hline
\end{tabular}


with TE (Tri-HCL $10 \mathrm{mM}$, EDTA $1 \mathrm{mM}, \mathrm{pH} 8.0$ ) to a concentration of $10 \eta \mathrm{g} \mu \mathrm{L}^{-1}$ for RAPD, $25 \eta \mathrm{g} \mu \mathrm{L}^{-1}$ for SSR and $50 \eta \mathrm{g} \mu \mathrm{L}^{-1}$ for AFLP analysis.

\section{RAPD molecular marker}

A total of 52 RAPD oligonucleotide primers (Operon Technologies) were analyzed. Each reaction constituted a total volume of $25 \mathrm{Ml}$, with $2.5 \mu \mathrm{L}$ of $10 \eta \mathrm{g} \mu \mathrm{L}^{-1}$ genomic DNA, $1.25 \mu \mathrm{L}$ of Taq DNA polymerase, $0.25 \mu \mathrm{L}$ of each dNTP, $1 \mu \mathrm{L}$ of primer, $2.5 \mu \mathrm{L}$ of $\mathrm{KCl}, 2.5 \mu \mathrm{L}$ of Tris $\mathrm{HCl} \mathrm{pH}$ 8.3 and $2 \mathrm{mM}$ of $\mathrm{MgCl}_{2}$. The PCR reaction was done using a thermo-cycle Gene Amp PCR System 9600. For the amplification, the DNA was denatured at $95^{\circ} \mathrm{C}$ for 1 minute followed by 40 cycles at $94{ }^{\circ} \mathrm{C}$ for 15 second to denature DNA, $35^{\circ} \mathrm{C}$ for 30 seconds to anneal the primer, $72{ }^{\circ} \mathrm{C}$ for 1 minute extension of the primer followed by final extension to complete the process of amplification at a temperature of $72{ }^{\circ} \mathrm{C}$ for 7 minutes and stored at $4{ }^{\circ} \mathrm{C}$ until used. The amplified DNA was separated using agarose gel electrophoreses $1.2 \%$. The gel was then immersed in the solution of Etidium Bromide and visualized using the Eagle Eye II Still Video System.

\section{SSR marker}

Eighteen microsatellite primers obtained from Combes et al. (2000) and Rovelli et al. (2000) were analyzed. The PCR reaction was realized in a total volume of $20 \mu \mathrm{L}$ containing $50 \eta \mathrm{g}$ of DNA, 0.6 unit of Taq DNA polymerase, buffer $1 \mathrm{x}, 1 \mathrm{mM}$ of $\mathrm{MgCl}_{2}, 150 \mu \mathrm{M}$ of each $\mathrm{dNTP}$ and $0.1 \mu \mathrm{M}$ of each primer. The amplification was done using the procedure of touchdown-PCR that consisted of denaturation at $94^{\circ} \mathrm{C}$ for 2 minutes, followed by 13 cycles of denaturation at $94^{\circ} \mathrm{C}$ for 30 seconds, primer annealing at $67^{\circ} \mathrm{C}$ to $55^{\circ} \mathrm{C}$ for 30 seconds, reducing $1{ }^{\circ} \mathrm{C}$ of each cycle and an extension of primer at $72{ }^{\circ} \mathrm{C}$ for 30 seconds. This step was followed by 30 more cycles of denaturation at $94^{\circ} \mathrm{C}$ for 30 seconds, primer annealing at $55{ }^{\circ} \mathrm{C}$ for 30 seconds and primer extension at $72{ }^{\circ} \mathrm{C}$ for 30 seconds. The final extension was done at $72{ }^{\circ} \mathrm{C}$ for 8 minutes. The PCR products were separated on a $6 \%$ denaturing polyacrylamide gel and visualized by a silver staining solution.

\section{AFLP analysis}

The AFLP genotyping of coffee accessions was done according to the method described by Brito et al. (2010). The primer combinations MseI-AGC with EcorI-CGT and MseIAGC with EcorI-CTC were used to genotype the coffee accessions in this study.

\section{Data analysis}

The gels of RAPD, SSR and AFLP were scored for the presence and absence of clearly amplified fragments. The data matrix was coded according to Falush et al. (2007) to fit for the analysis of Structure program assuming a correct model of dominance. AFLP data statistical package (Ehrich 2006) was used to manage the data conversion from txt format to Structure and Arlequin data format.

To study the genetic diversity, the Jaccard genetic distance (1- Jaccard similarity coefficient) (Jaccard 1908), Nei genetic diversity index (Nei 1973), Shannon's Information Index and percent polymorphic bands (P \%) were estimated, using Popgene software version 1.3 (Yeh and Boyle 1997). Principal coordinate analysis ( $\mathrm{PCoA})$ was performed using the GenAlex 6.2 population genetic analysis software (Peakall and Smouse 2006).

To define the population structure of the "Híbrido de Timor" coffee accessions, the Bayesian model-based clustering method of Pritchard et al. (2000) was implemented in the Structure 2.1 software (http://www.pritch.bsd. uchicago.edu/) to estimate population admixture through inferred ancestry. For each of the $\mathrm{K}=2$ to $\mathrm{K}=12$ settings, 20 independent simulations were performed using the admixture model and 5000 replicates for burn-in and post burning sampling by Markov Chain Monte Carlo of 50,000 runs to estimate the number of subpopulations for each of the $\mathrm{k}$ values. The appropriate number of clusters $(\mathrm{K})$ was determined according to Evanno et al. (2005).

\section{RESULTS AND DISCUSSION}

\section{Genetic diversity analysis}

The AFLP, RAPD and SSR molecular markers produced 80, 120 and 25 polymorphic alleles among accessions of "Híbrido de Timor", respectively. The population diversity parameters estimated on "Híbrido de Timor" coffee was presented on Table 2. These genetic diversity measures showed that the Híbrido de Timor germplasm has considerable genetic diversity.

The estimated Genetic dissimilarity coefficient (1Jaccard similarity coefficient) was used in principal coordinate analysis (PCoA). Before doing the PCoA, the Mantel test between the distance matrix produced by AFLP, RAPD and SSR variation was performed. The test showed significant correlation among them so that the combined data was used for further analysis. PCoA using the combined data from AFLP, RAPD and SSR markers 
Table 2. The Nei gene diversity measure, Shannon's information index and percent polymorphic bands ( $\mathrm{P} \%$ ) obtained using AFLP, RAPD and SSR molecular markers for "Híbrido de Timor" coffee accessions

\begin{tabular}{lccc}
\hline & Nei gene diversity & $\begin{array}{c}\text { Shannon's Information } \\
\text { Index }\end{array}$ & P (\%) \\
\hline AFLP & 0.135 & 0.220 & 56.48 \\
RAPD & 0.153 & 0.228 & 46.50 \\
SSR & 0.059 & 0.092 & 25.00 \\
\hline
\end{tabular}

formed a clear grouping pattern (Figure 1). The first two principal coordinates explained $66.83 \%$ of the total variation among the accessions (Figure 1). In addition, the clustering analysis using the UPGMA method based on the combined data of the three molecular markers formed three principal cluster groups (Figure 2). The CIFC4106, considered the first plant found in the Timor Island (Pereira et al. 2005), grouped together with CIFC 832/1, CIFC 832/2, and CIFC 1343/269 introduced in CIFC from Timor Island by seed (Betencourt 1973) and sent to Brazil via vegetative propagation. These groups also included accessions of "Híbrido de Timor" introduced by seed to UFV from CIFC.

Both the genetic distance based analysis of diversity and population based statistics (percent polymorphic loci, Nei gene diversity index and Shannon's index) demonstrated the efficiency of the three molecular markers in detecting genetic diversity among "Híbrido de Timor" accessions found in the germplasm bank of UFV/Epamig.

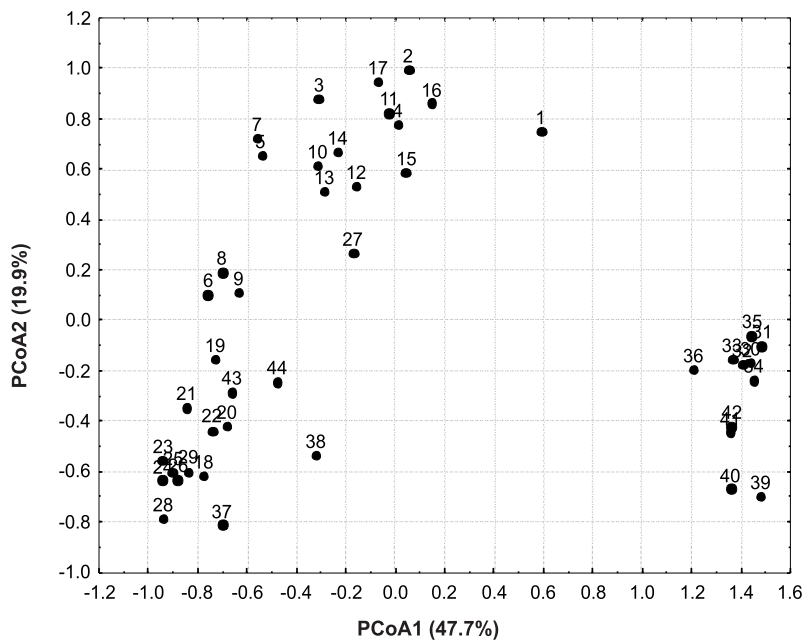

Figure 1. Principal coordinate analysis of the combined data from AFLP, RAPD and SSR diversity among accessions of "Híbrido de Timor" coffee (Numbers correspond to the code of the accessions in Table 1).

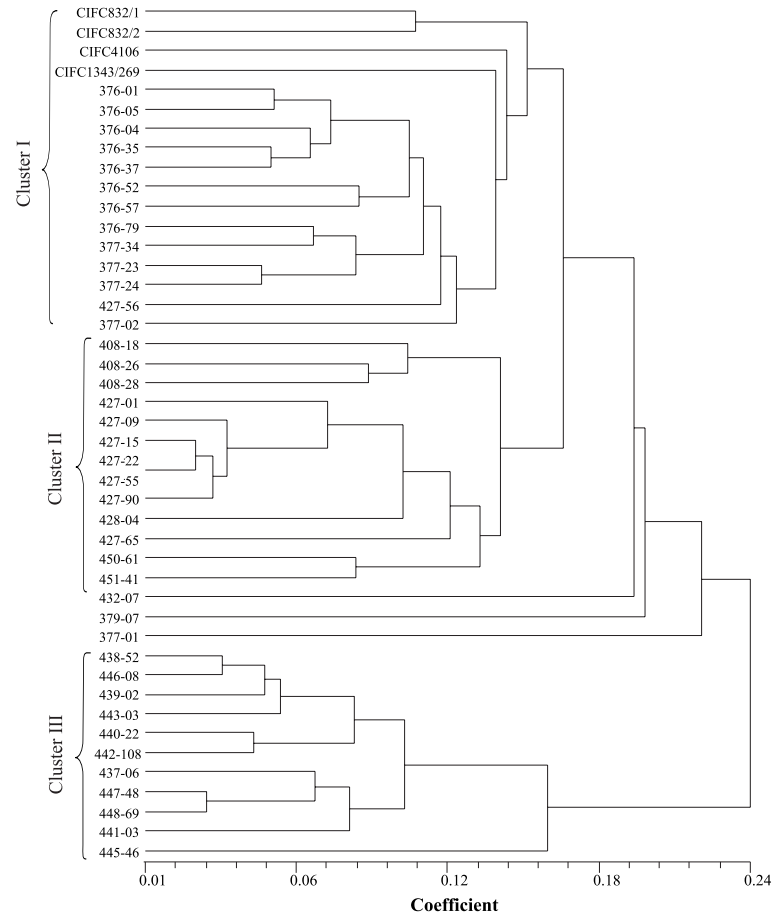

Figure 2. The dendrogram produced based on Genetic dissimilarity of Jaccard estimated based on the combined data of AFLP, RAPD and SSR molecular markers using the UPGMA cluster method for "Híbrido de Timor" coffee

\section{Genetic Structure}

To understand the genetic structure of the "Híbrido de Timor" accessions the clustering analysis based on the Bayesian statistical analysis was performed using the Structure program (Pritchard et al. 2000). This analysis, using the data from the three molecular markers, grouped the accessions into three clusters. Eighty nine percent of the accessions were assigned in their respective group with a shared ancestral probability higher than 0.81 (Table 3). CIFC 4106, considered the first "Híbrido de Timor" plant found on Timor Island (Pereira et al. 2005), grouped with the other CIFC materials with a shared ancestral probability greater than $90 \%$. This result agreed with the historical information that this plant gave way to the origin of these "Híbrido de Timor" accessions. Under Viçosa soil and climatic condition, CIFC 4106 had high flowering capacity but produced a small amount of fruit, all with moka type seeds, which indicates the occurrence of self-incompatibility (Pereira et al. 2008). Additional field observations showed that no artificial hybridization succeeded, when CIFC 4106 was used as the female parent. On the other hand, when 
TA Setotaw et al.

Table 3. Shared ancestral probability of each accessions of "Híbrido de Timor" in relation to three clusters inferred based on AFLP, RAPD and SSR variation using Bayesian clustering analysis

\begin{tabular}{|c|c|c|c|c|}
\hline \multirow{2}{*}{ Code } & \multirow{2}{*}{ Name of accession } & \multicolumn{3}{|c|}{ Inferred cluster } \\
\hline & & I & II & III \\
\hline 1 & CIFC832/1 & 0.308 & 0.689 & 0.002 \\
\hline 2 & CIFC832/2 & 0.028 & 0.968 & 0.004 \\
\hline 3 & CIFC4106 & 0.009 & 0.972 & 0.019 \\
\hline 4 & CIFC1343/26 & 0.017 & 0.978 & 0.005 \\
\hline 5 & UFV376-01 & 0.002 & 0.966 & 0.031 \\
\hline 6 & UFV376-04 & 0.003 & 0.481 & 0.516 \\
\hline 7 & UFV376-05 & 0.002 & 0.989 & 0.010 \\
\hline 8 & UFV376-35 & 0.003 & 0.55 & 0.447 \\
\hline 9 & UFV376-37 & 0.009 & 0.541 & 0.451 \\
\hline 10 & UFV376-52 & 0.004 & 0.971 & 0.026 \\
\hline 11 & UFV376-57 & 0.005 & 0.992 & 0.003 \\
\hline 12 & UFV376-79 & 0.010 & 0.961 & 0.029 \\
\hline 13 & UFV377-01 & 0.004 & 0.818 & 0.179 \\
\hline 14 & UFV377-02 & 0.004 & 0.943 & 0.053 \\
\hline 15 & UFV377-23 & 0.01 & 0.98 & 0.01 \\
\hline 16 & UFV377-24 & 0.011 & 0.986 & 0.003 \\
\hline 17 & UFV377-34 & 0.005 & 0.992 & 0.003 \\
\hline 18 & UFV379-07 & 0.007 & 0.004 & 0.989 \\
\hline 19 & UFV408-18 & 0.003 & 0.046 & 0.951 \\
\hline 20 & UFV408-26 & 0.003 & 0.008 & 0.989 \\
\hline 21 & UFV408-28 & 0.002 & 0.011 & 0.987 \\
\hline 22 & UFV427-01 & 0.005 & 0.018 & 0.978 \\
\hline 23 & UFV427-09 & 0.002 & 0.004 & 0.994 \\
\hline 24 & UFV427-15 & 0.002 & 0.005 & 0.994 \\
\hline 25 & UFV427-22 & 0.002 & 0.004 & 0.994 \\
\hline 26 & UFV427-55 & 0.002 & 0.004 & 0.994 \\
\hline 27 & UFV427-56 & 0.084 & 0.75 & 0.165 \\
\hline 28 & UFV427-65 & 0.002 & 0.002 & 0.996 \\
\hline 29 & UFV427-90 & 0.005 & 0.004 & 0.991 \\
\hline 30 & UFV438-52 & 0.996 & 0.002 & 0.002 \\
\hline 31 & UFV439-02 & 0.997 & 0.002 & 0.001 \\
\hline 32 & UFV440-22 & 0.996 & 0.002 & 0.002 \\
\hline 33 & UFV442-108 & 0.992 & 0.006 & 0.002 \\
\hline 34 & UFV443-03 & 0.997 & 0.002 & 0.001 \\
\hline 35 & UFV446-08 & 0.996 & 0.002 & 0.001 \\
\hline 36 & UFV445-46 & 0.933 & 0.015 & 0.052 \\
\hline 37 & UFV428-04 & 0.004 & 0.003 & 0.993 \\
\hline 38 & UFV432-07 & 0.170 & 0.014 & 0.816 \\
\hline 39 & UFV437-06 & 0.997 & 0.002 & 0.001 \\
\hline 40 & UFV441-03 & 0.997 & 0.001 & 0.002 \\
\hline 41 & UFV447-48 & 0.997 & 0.002 & 0.002 \\
\hline 42 & UFV448-69 & 0.994 & 0.004 & 0.002 \\
\hline 43 & UFV450-61 & 0.006 & 0.029 & 0.966 \\
\hline 44 & UFV451-41 & 0.027 & 0.121 & 0.853 \\
\hline
\end{tabular}


used as a male parent (donor of pollen), there was some success in crossing with a low percentage of fertilization (Pereira et al. 2008). These field observations support the hypothesis that CIFC 4106 originated from natural interspecific hybridization between $C$. arabica and C. canephora, as suggested by Pereira et al. (2005).

The combined data from RAPD, SSR and AFLP molecular markers grouped the accessions CIFC 832/1, CIFC 832/2 and CIFC 1343/269 in the same cluster with a shared ancestral probability greater than $68.9 \%$. These accessions were the first genetic material, collected from the same plant on Timor Island, sent to CIFC (Bettencourt 1973). These plants were introduced to Brazil through vegetative propagation. Still these accessions were used for the development of arabic coffee cultivars with durable and complete resistance to coffee leaf rust all over the world (Bettencourt 1973, Pereira et al. 2005, Zambolim et al. 2005).

All the accessions derived from UFV 377 and five accessions derived from UFV 376 (UFV 376-01, UFV 37605, UFV 376-52, UFV 376-57 and UFV 376-79) were grouped together in Cluster II with a shared ancestral probability greater than 0.81 . The other three accessions derived from UFV 376 shared some level of allele with group II and III. These accessions have a common origin. A plant designated as VCE1587, resistant to leaf rust, was selected in Tanzania. Seeds of this plant were taken to CIFC, from which two plants were selected and designated as CIFC 2234 and 2235. Later on, seeds from CIFC 2234 and 2235 were sent to IIAA (Instituto de Investigação Agronômica de Angola), under the code IIAA808 and IIAA811, respectively. The UFV376 and UFV377 originated from seeds collected in the IIAA808-5 and IIAA811-5 plants, respectively. UFV 437, UFV 438, UFV 439, UFV 440, UFV 441, UFV 442, UFV 443, UFV 445, UFV 446, UFV 447 and UFV 448 were grouped in Cluster I. These accessions were derived from CIFC 2570 (Table 1). The accessions that originated from ERU202 (derived from CIFC 1343/136) were grouped in Cluster III. This cluster was also composed of coffee derived from CIFC 2252, CIFC 1590/9, CIFC2568 and CIFC2571.

In general the grouping pattern using the Bayesian model-based clustering method (Pritchard et al. 2000) was in agreement with the origin of accessions. Most of the accessions derived from the same plant by seed propagation grouped together with a shared ancestral probability $>0.80$. López-Gartner et al. (2009) also proved the efficiency of the model based Bayesian clustering analysis for studying the genetic diversity and structure of arabic coffee originating from Ethiopia.

The economic and environmental benefit and the high cup quality aspects of the arabica coffee cultivars derived from "Híbrido de Timor" were previously reported (Pereira et al. 2005, Pereira et al. 2008, van de Vossen 2009). Our data clearly showed that the genetic variability of the Híbrido de Timor germplasm is potentially useful for breeding programs, especially because of the well known narrow genetic basis of $C$. arabica. Additionally, we have organized the variability of this germplasm, in such a way that a breeder can choose parental plants according to the objectives in his/her breeding program. For instance, a new parental plant can be chosen based on the criteria of the genetic similarity or dissimilarity with CIFC 832/1 and CIFC 832/2, the major sources of genes for resistance to coffee leaf rust (Bettencourt 1973), depending on the disease resistance, productivity, cup quality, and other characteristics considered. Our results can also be applied to germplasm management. A small number of each of the three clusters identified in this study can well represent the Híbrido de Timor germplasm if a sub-collection is needed, with the advantage of preserving the original variability with low cost and labor.

\section{ACKNOWLEDGEMENTS}

The authors wish to thank CNPq and TWAS for the financial support and scholarships. 


\title{
Potencial de melhoramento e diversidade genética do café "Híbrido de Timor" avaliado por marcadores moleculares
}

\begin{abstract}
RESUMO - Marcadores moleculares AFLP, RAPD e SSR foram usados para estudo da diversidade e estrutura genética do germoplasma de Híbrido de Timor. As análises de coordenadas principais, de agrupamento UPGMA baseado na dissimilaridade genética de Jaccard, de agrupamento baseado no modelo Bayesiano, a percentagem de locos polimórficos, o índice de Shannon e a diversidade genética de Nei foram utilizadas para acessar a diversidade genética. As análises demonstraram alta diversidade genética entre os acessos de Híbrido de Timor. A análise de agrupamento UPGMA e o modelo Bayesiano permitiram a alocação dos acessos em três grupos. A estrutura genética dos acessos de Híbrido de Timor foi descrita. A manutenção e manuseio da variabilidade do germoplasma de Híbrido de Timor e seu potencial uso nos programas de melhoramento de cafeeiro foram discutidos.
\end{abstract}

Palavras-chave: Melhoramento do cafeeiro, marcadores de DNA, resistência à ferrugem, análise bayesiana, análise de coordenadas principais.

\section{REFERENCES}

Bettencourt A (1973) Considerações gerais sobre o 'Híbrido de Timor'. Secretaria da Agricultura do Estado de São Paulo, Campinas, 20p. (Circular 23).

Brito GG, Caixeta ET, Gallina AP, Maciel-Zambolim E, Zambolim L, Diola V and Loureiro ME (2010) Inheritance of coffee leaf rust resistance and identification of AFLP markers linked to the resistance gene. Euphytica 173: 255-264.

Carvalho A, Fazuoli LC and Costa WM (1989) Produtividade do Híbrido de Timor, de seus derivados e outras fontes de resistência a Hemileia vastatrix. Bragantia 48: 73-86.

Charrier A and Eskes A (1997) Coffee. In Charrier A, Jacquot S, Hamon D and Nicolas C (eds.) Tropical plant breeding. Cirad, Repères, p. 128-152.

Chaves GM (1976) Melhoramento do cafeeiro visando à obtenção de cultivares resistentes à Hemileia vastatrix Berk et Br. Revista Ceres 23: 321-332.

Combes MC, Andrzejewski S, Anthony F, Bertrand B, Rovelli P, Graziosi G and Lashermes P (2000) Characterization of microsatellites loci in Coffea arabica and related coffee species. Molecular Ecology 9: 1171-1193.

Diniz LEC, Sakiyama NS, Lashermes P, Caixeta ET, Oliveira ACB, Maciel-Zambolim E, Loureiro ME, Pereira AA and Zambolim L (2005) Analysis of AFLP marker associated to the Mex-1 resistance locus in Icatu progenies. Crop Breeding and Applied Biotechnology 5: 387-393.
Ehrich D (2006) AFLPdat: a collection of R functions for convenient handling of AFLP data. Molecular Ecology Notes 6: 603-604.

Evanno G, Regnaut S and Goudet J (2005) Detecting the number of clusters of individuals using the software Structure: A simulation study. Molecular Ecology 14: 2611-2620.

Falush D, Stephens M and Pritchard JK (2007) Inference of population structure using multilocus genotype data: dominant markers and null alleles. Molecular Ecology Notes 7: 574578 .

Gonçalves W and Pereira AA (1998) Resistência de cafeeiros a nematóides IV-reação de cafeeiros derivados de Híbridos de Timor a Meloidogyne exigua. Nematologia Brasileira 22: 39-50.

Jaccard P (1908) Nouvelles recherches sur la distribution florale. Bulletin de la Societé Vanddoise des Sciences Natureles 44: $223-270$.

Lashermes P, Andrzejewski S, Bertrand B, Combes MC, Dussert S, Graziosi G, Trouslot P and Anthony F (2000) Molecular analysis of introgressive breeding in coffee (Coffea arabica L.). Theoretical and Applied Genetics 100: 139-146.

López-Gartner G, Cortina H, McCouch SR and Moncada MDP (2009) Analysis of genetic structure in a sample of coffee (Coffea arabica L.) using fluorescent SSR markers. Tree Genetics and Genomes 5: 435-446. 